\title{
On the Foundation and Early Fasti of Peterborough
}

\section{The Rev. William Stubbs}

To cite this article: The Rev. William Stubbs (1861) On the Foundation and Early Fasti of Peterborough, Archaeological Journal, 18:1, 193-209, DOI: 10.1080/00665983.1861.10851181

To link to this article: http://dx.doi.org/10.1080/00665983.1861.10851181

曲 Published online: 10 Jul 2014.

Submit your article to this journal $\pi$

Џll Article views: 3

Q View related articles $\square$ 


\title{
$\mathfrak{C H}_{\mathfrak{y}}$ Arthaedogical 3ournal.
}

\author{
SEPTEMBER, 1861.
}

\section{ON THE FOUNDATION AND EARLY FASTI OF PETERBOROUGH. ${ }^{1}$}

BY THE REV. WILLIAM STUBBS, Vicar of Navestock.

Perhaps one of the most important offices of the archæologist is to aid the critical study of history, by clearing away the false and forged from the true and genuine remains of past ages, and by eliminating the false and misleading expressions that are found in records whose facts and principles are true. It is impossible to say how greatly the knowledge of our early history has been retarded by the pseudo-Ingulf; how many learned disquisitions are utterly valueless, and how many standard works must be regarded with suspicion, because their arguments or statements rest on the contents of that unlucky book. ${ }^{2}$

It is extremely unfortunate that so much of our early ecclesiastical history is mystified, partly by the real, partly by the suspected existence of such fabrications. The extraordinary clearness and brightness, and the indisputable genuineness of Bede's narrative, throw into deep gloom the twilight glimpses of the Anglo-Saxon Chronicle;-if we turn from them to the lives of the saints and the monastic histories, the mixture of fable throws a general incredibility into what very possibly is true in the main; and if we go to charters we know that every step of our investigation must be tried by diplomatic tests, before we can safely tread.

The history of the Fen Monasteries, Peterborough and

1 Communicated to the Historical at Peterborough, July 29, 1861. Section at the Meeting of the Institute ${ }_{2}^{2}$ Lappenberg, Maitland.

vol. xVIII. 
Croyland most especially, disappoints our hopes in proportion as the apparent abundance of materials has raised them. There seems to be no lack. Besides Ingulf we have the goodly volume of Chronicles edited by Sparke, the Peterborough History edited by the late Mr. Stapleton for the Camden Society, the Peterborough copy of the AngloSaxon Chronicle, invaluable chartularies, we can refer for supplementary aids to the Chronicles of Ramsey and Ely. But what is to be said when we find the fullest Peterborough History copying its most interesting portions straight from Ingulf, ${ }^{1}$ and the Peterborough copy of the Chronicle owing its local importance to misused and fabricated charters, - in fact, only a few glimpses of truth in a whole library of inventions. Not that I would be equally severe on all fabricators; a forged charter may be true in every point but its form : it may, e.g., be a record of a donation, drawn up long after the donation itself was made, the donation having been made in days when records were not deemed necessary, the record being framed to satisfy a necessity younger than the donation it records. ${ }^{2}$ Or it may have been drawn up to supply the place of a lost original, and so contain, among words and forms that did not exist in that original, no statement that is not true, these forms being got rid of: and in general I should require, for the unhesitating cashiering of a charter, proof of two points,1st, of the existence of an interest or probable interest in a fraud: 2nd, a diplomatic anachronism. ${ }^{3}$ I mention this, though the principle is doubtless familiar to many of my readers, because in the remarks I have to make I shall have to refer to spurious, doubtful, and genuine charters, and I wish that there should be no misapprehension of my notion as to their respective values.

The country of the Gyrvii seems to have been, when we first read of it, a sort of debateable ground between Mercia

1 On examining the MS. of John of Peterborough, Claudius A. 5, I find that in the original there was from 868 to 890 a blank left, which was filled up in the 16 th or 17 th century with extracts from Ingulf.

${ }^{2} E . g_{\text {, }}$ charters of foundation, which (genuine) are extremely rare-even to late times.
3 As we may be pretty sure that no unsuccessful forgery of a charter would be preserved-the occurrence in a charter of a claim to lands or rights by a particular house or person, not known from other sources ever to have had such lands or rights, is prima facie evidence of the genuineness of a charter, not as it is sometimes taken, of the reverse. 
and East Anglia. I It extended south and north from the river Granta to the sea; east and west from the boundary of the Isle of Ely to the borders of Northamptonshire. ${ }^{2}$ It was in point of fact the fen country, and the Gyrvii were the dwellers in the many wooded islands that rose above the level of the marshes. The northern Gyrvii must have held south Lincolnshire, and parts of north Cambridgeshire and Northamptonshire: the south Gyrvii, as we may infer from the fact that $\mathrm{S}$. Etheldreda, the widow of their prince Tonberht, settled in the Isle of Ely, must have occupied South Cambridgeshire. ${ }^{3}$ Each division contained 600 hides, according to the "Numerus Hydarum." 4 The Isle of Ely, which contained the same number of hides, was, according to Bede, ${ }^{5}$ a province of East Anglia. The political affinities of the tribe were, like the physical affinities of their country, rather with East Anglia than with Mercia: ${ }^{6}$ possibly their independence lasted longer than that of the other tribes that contributed to the

${ }^{1}$ Gyrvii vocantur lii qui juxta paludem vel infra paludem habitant. Nam Gyr, Anglice, Latine profunda palus dicitur. H. Cand. p. 2.

2 Felix. V. S. Guthlac. p, 260.

3 Bede IV. 19.
${ }^{4}$ Gale 748.

5 Bede IV. 19.

6 This may be seen in the following descent of the kingdom of East Anglia and of that of Mercia:-

SEni.

\begin{tabular}{|c|c|c|c|c|c|}
\hline & Anna, 63 & -654 & Ethelhere, 654 & -655 & $\begin{array}{l}\text { Athelwold, } \\
655-664 .\end{array}$ \\
\hline $\begin{array}{l}\text { Sexburh, } \\
\text { m. Erconberht, } \\
\text { k. Kent. } \\
\text { 2nd Abbess } \\
\text { of Ely. }\end{array}$ & $\begin{array}{l}\text { Ethelburh, } \\
\text { Abbess of } \\
\text { Brie. }\end{array}$ & $\begin{array}{l}\text { Etheldreda, } \\
\text { m. 1. Tunberht, } \\
\text { P. of Gyrwas. } \\
\text { 2. Ecgfrith, k. of } \\
\text { Northumber- } \\
\text { land : d. } 679 \text {, } \\
23 \text { June. } \\
\text { 1st Abb. of Ely. }\end{array}$ & $\begin{array}{c}\text { Eald wulf, } \\
663-713 . \\
\text { Eadburh, } \\
\text { Abb. } \\
\text { Repton. }\end{array}$ & $\begin{array}{l}\text { Alfwold } \\
713-749\end{array}$ & \\
\hline
\end{tabular}

Penda.

Peada, Wulfhere, Cyne- Cyneburh, Merewald, Merchelm. Wilburh, Ethelred,

d. 656. 656-675. switha, m. Ealh- S. of Penda, m. Fritho- 675-704. m. gild. Burgh North.: pneva. North.: pneva. k. Surrey. Ceolred. nun at Burgh S. Osyth. m. WerCastle. burh.

Cenred, S. Wer- Beorbt- Mildred, Milburh, Mildgyth. Mere-

704-709. burh, wald. 2nd Abb. S. at Abbess at Minster. Wenlock.

Chester. 
late formation of the Mercian kingdom. We can indeed only guess at this from the little we know of their history, but the guess gains some probability from a glance at their early ecclesiastical organisation. Botolph, the founder of Boston, is spoken of in close connection with Anna, king of the East Angles. ${ }^{1} \quad$ S. Etheldreda was a daughter of Anna: Ely, as we have just seen, is placed by Bede in East Anglia. Felix dedicates his life of S. Guthlac to Ethelwald, or Elfwald, king of East Anglia ; and Ethelbald, the royal exile of Mercia, takes refuge in the marshes of Croyland from the pursuit of Cenred and Ceolred, choosing this retreat, not only as inaccessible, but because it was outside of the immediate jurisdiction of Mercia. Florence of Worcester says that Cambridgeshire was a part of the East Anglian kingdom ${ }^{3}$ a statement which is copied by William of Malmesbury, ${ }^{4}$ and may very probably have been copied by Florence from an earlier record.

To the fact that the Gyrvii were so far East Anglian we may attribute their being Christianised much earlier than their Mercian neighbours: for Thomas, the second native Englishman who was consecrated a bishop, was a native of this province. ${ }^{5} \mathrm{He}$ was appointed to succeed S. Felix of Dunwich, in 647 , five or six years before the conversion of the Middle Angles began under Peada.

Mercia, late in its formation as a kingdom, sprang at once into a great state under Penda: late in its adoption of Christianity, it seems from the period of its conversion to have taken a prominent place at once among the Christian powers. The Chronicle places the conversion in 655 , and a very few years saw it the best governed and best organised province of the Church. In less than thirty years it was divided into five dioceses, amongst which the place of the Fen country is more clearly definable. The bishopric of Lindsey occupied the north of Lincolnshire, reaching to the Witham : a line drawn from the south point of Nottinghamshire to the Cam would probably represent the western border of the Gyrvii : the border of Cambridgeshire was

1 Chr. Sax. 654.

2 Vita S. Guthlac, MS. Colton. Nero. E. I. Mab. Acta. SS. Ord. Bened. III. 256.

${ }^{3}$ Reges Orientalium Anglorum dominabantur in pago Grantebrigensi; et est ibi episcopus cujus sedes est apud Hely. F. W. I. 278. Mark the bearing of this on the antiquity of Cambridge. Cf. Sigeberht's Schools, Bede III. 19.

4 Malms. G. R. I. 105.

5 Bede III. 20. 
the boundary of the dioceses of Elmham and Dunwich. The Fen country thus falls into the eastern portion of the great Lichfield diocese, which for a few years after 680 had its own bishop at Leicester, but was not finally separated from the mother see until 737. From the time of the conversion of Mercia the northern fens were certainly Mercian: Bede's placing Ely in East Anglia is conclusive for that portion. ${ }^{1}$ It is Bishop Hedda of Lichfield who ordains S. Guthlac at Croyland. ${ }^{2}$ The connection between Ely and East Anglia lasted long. ${ }^{3}$ The abbots before the Conquest were blessed by the bishops of Elmham, although the isle and the county of Cambridge were both in the limits of the diocese of Dorchester and Lincoln. This is to be ascribed to the claims of exemption made by the monastery from episcopal jurisdiction : they would not receive benediction from Dorchester-they must have it, and sought it, from the nearest bishop, who could not turn it into a right of jurisdiction. ${ }^{4}$

That the Fen country presented charms enough to the monastic minds of later ages is plain, from the praises lavished upon it by the writers of the time of the Conquest. ${ }^{5}$

1 Bede IV. 19.

2 Mabillon supposes this to be the West Saxon Bp. Hedda of Dorchester, 676 -705 , but this is almost impossible. Vita S. Guth. p. 270.

3 Lib. Eliens. : Ang. S. I. 608.

4 When the diocese of Ely was created, the Bishop of Lincoln received the town of Spaldwick, or Spalding, as compensation for his rights over the isle and county of Cambridge. Ang. Sac. I. 616; Malmsb. G. P. Lib. IV. p. 1612.

5 Est autem palus illa de qua loquimur latissima, et visu decora, multis fluviis decurrentibus irrigata, multis lacubus magnis et parvis depicta, multis etiam silvis et insulis florida; intra quam sunt ecclesia Heliensis, abbatia Ramesiensis, abbatia Chateric, abbatia Thorneia, abbatia Crulande, sed juxta eam sunt abbatia Burgensis, Abbatia Spaldinge, ecclesia S. Ivonis super Usam fluvium Huntendoniæ, ecclesia S. Egidii super Grentam fluvium Cantabrigix, ecclesia $\mathrm{S}$. Trinitatis in Tedfordia. H. Hunt. p. 747.

Heli stagnantium insularum maxima ab anguillarum copia ita dicta;--denique illorum et omnes pene amnicorum piscium generis tanta est copia, ut sit adveuis miraculo, indigenis pro illorum admiratione ludibrio. Nec minor aquaticarum volucrum vilitas, ut pro uno asse de utroque cibo quinque homines et eo am. plius non solum famem pellant sed et satietatem expleant. Malmsb. G. P. IV. p. 1611.

Burch vero in regione Gyrviorum est fundatus, quia ibi incipit eadem palus in orientali parte quæ per milliaria sexaginta vel amplius durat. Est autem eadem palus hominibus permaxime necessaria, quia ibi accipiuntur ligna et stipula ad ignem et fonum ad pabula jumentorum et coopertorium ad domos cooperiendas, etc. etc., estque ex omni parte formosus, etc. H. Cand. p. 2.

Thorneia-Paradisi simulacrum quod amœnitate jam ccelos ipsos imaginetur, in ipsis paludibus arborum ferax quæ enodi proceritate luctantur ad sidera, æquorea planities herbarum viridantibus comis oculos advocat; currentibus per campum nullus offensioni datur locus. Nulla ibi vel exigua terræ portio vacat; $h$ ic in pomiferas arbores terra se subigit; hic præ. texitur ager vineis quæ vel per terram repunt vel per bajulos palos in celsum surgunt. Malmsb. G. P. IV. 1613.

Ex inundatione vel ex superfluitione amnium stans aqua inæquali terra profundan paludem efficit, itaque inhabitabilem reddit præeter quædam lock altiora 
They laud it especially for its wide extent, beautiful prospects, streams and lakes, woods and islands: its abundant fisheries, plenty of wood, hay for cattle, straw for thatching, \&c., the quantity of game and waterfowl; it is altogether beautiful, says Hugo Candidus. The eels are so plentiful in Ely, that the unrestrained astonishment of visitors provokes the phlegmatic natives to laughter. Waterfowl are so cheap that five men may dine luxuriously for a penny. Thorney is a reduced copy of paradise; its straight, smooth, knotless trees reach the stars; its level plains are like the sea in extent and verdure. All the land is covered with cultivation; here are apple-trees, there vineyards, managed (the historian carefully tells us) in both methods of vine culture, both on the ground and on trellised poles. Ramsey also is praised in hardly less enthusiastic language. ${ }^{1}$

But it was not with a view to such advantages as these that this district was originally chosen as the garden of English monasticism; rather these very beauties were to be ascribed in some measure to the effects of monastic occupancy. The earlier writers describe things much less pleasantly. Croyland was a place full of horrors-a cloudy, remote, and desolate wilderness; desolate with unknown monsters and diverse shapes of terrors-devils in the forms of wild beasts, boars, wolves, horses, cows, crows, and Britons. ${ }^{2}$ Bede had nothing better to say of Ely than that it abounded in eels. ${ }^{3}$ But in truth the country was well suited to the then stage of English monastic life. It was convenient both for the missionary and for the anachoretic life. It was secluded, and yet near to the centres of population: it was politically possessed of a sort of quasi independence that afforded security to the missionaries sent from Christian Gyrvia into half-converted Mercia. A very slight acquaintance with English church history shows us that these were great points. Medeshamstede might be to the Middle Angles what Glastonbury was to Wessex and

quæ credo quod ad hoc Dominus illa extulit, ut habitacula fierent servorum Dei, qui ibi habitare elegissent. H. Cand. p. 2.

Ramsey-Est autem locus diverso arborum genere saltuosus, in quodam sinu suo fecundæ cespitis gratam habens planitiem, denso graminum vellere pastu pecorum detondendo vesitum, \&c. Hist. Rams.
Gale. p. 397.

For the other side of the picture, $v$. Felix. Vita S. Guthlac, p. 260, and passim.

1 Abbatiam Ramsei in insula pulcher. rima intra easdem paludes. H. Hunt. p. 747 .

2 Vita S. Guth, p. 263.

3 Bede IV. 19. 
the British country, and here a Mercian Cuthbert might find his Farne and Lindisfarne close together.

Medeshamstede, founded on the edge of the Marsh, was then principally a missionary station, though with great facilities for retreat. Croyland, founded nearly a century later, was a purely anachoretic one. The two lives were indeed the complements of one another : ${ }^{1}$ the divorce between the two, in the case of Croyland, marks a period of change consequent on the completion of the conversion of the country. Thinking of the earlier anchorites, we might for a moment look on the change with allowance and sympathy : knowing, as we do, from $\mathrm{S}$. Boniface and Bede, the real history of the monasteries of the age, we view it only as a sign of declension-decline into a condition in which hospitality and manual industry seem to have been the only redeeming virtues of an epoch of worldliness and self-indulgence.

Both the anachoretic and the missionary spirit were strong in the family of Penda; the former chiefly among the women, the latter among the men of the house : nearly all his children and grandchildren died in the odour of sanctity; not a few among them were canonised by the gratitude of the people they blessed. The Peterborough historians ascribe the foundation of Medeshamstede to the true missionary Peada; and its increase and enrichment to Wulfhere and Athelred, prompted by their sisters Cyneswitha and Cyneburga, abbess of Burgh Castle. The account given in the Peterborough copy of the Saxon Chronicle is unfortunately so irreconcileable with historical dates as to be quite devoid of authority. Bede, omitting all mention of the royal family, ascribes the foundation to Saxulf, the first abbot: $:_{1}^{2}$ still I think we must not begrudge the princes their share in the act, though we may not believe the circumstantial account given by the chronicler of the ceremony of consecration, or the speeches made on the occasion ; and though we may incline to the belief that the boundaries of the endowment lands belong rather to the age of Edgar than that of Wulfhere,-still, knowing the character of the Mercian princes and the uniformity of the tradition, we may conclude that Saxulf was not without their aid in his good

1 Cf: Portroyal. For Croyland recluses, V. Bronton, 752.

2 Bedo IV, 6. 
work. The portion of the Chronicle which professes to give the history of this event is of as late date as 1122 ; we have an earlier account, certainly not later than the age of Ethelwold (963), but which professes to be the relation of Hedda, the last abbot before the destruction by the Danes in 870 , and which we may suppose was preserved as one of the documents concealed in the wall by him before the sacking, and discovered on the restoration under Edgar. This is set down by Sparke as a forgery ; but, forgery or not, it is an earlier history of the traditional foundation than is elsewhere extant. It is found in the MS. Soc. Antiq. LX., in Hugo Candidus, and elsewhere. ${ }^{1}$ If it is a forgery it is one of the age of Edgar. According to this, Peada, having been baptized by Finan, under the persuasion of his brother-in-law, Ealhfrid, began the evangelizing of Middle Anglia, with the aid of the four missionaries and of Saxulf, a thane of great riches and reputation, who founded Medeshamstede, and dedicated it to $\mathrm{S}$. Peter as the firstfruits of the Mercian church. The foundation was favoured by Oswy, Wulfhere, and Fthelred : daughter monasteries sprang up around it; Saxulf, like the wise Simon the Maccabee, strengthened his stakes and lengthened his cords. In this account, as in Bede, Saxulf is the principal figure : according to this relation the date of foundation falls in the pontificate of Deusdedit, $655-664$.

We may then accept the date of the Chronicle, 655. In 657 Peada died, and, after a short occupation by Oswy, Wulfhere succeeded : to him the endowment of the abbey by charter is attributed. $A$ priori, we feel inclined to reject charters of foundation : this charter of Wulfhere we have no hesitation in calling a forgery. There are two editions of it, besides the abstract given in the Chronicle. The more ancient of these, which agrees in most points with the abstract, is found in the Chartulary MS. Soc. Ant. LX. The later edition is printed by Kemble from several MSS. ${ }^{2}$ Both are spurious: the more modern fabrication is of later date than the Conquest, probably later than 1122: it contains a grant,-I., of lands about Peterborough ; II., of divers lands in other counties. Of this second class of

1 H. Candidus, p. 23. Mon. Angl. I. 375. MS. Soc. Ant. LX. f. 53, b.
2 Kemble, Cod. Dipl. 981. Mon. Angl. I., 377 . 
possessions the genuine original grants have come down to us : they are all later than Wulfhere's time, and some of them as late as the reign of Edward the Confessor. As to the first class, the boundaries of the Peterborough lands are the same in the three authorities, but they are apparently taken from the charter of restoration by Edgar, which charter, though marked spurious by Kemble, does not bear any decisive marks of forgery. It is not improbable that the original forgery of Wulfhere's charter was of the same date. Appended to this last is a confirmation by Pope Vitalian, which has no pretension to genuineness. The record of the dedication must also be rejected, as containing many improbabilities, and resting on no authority.

In 675, Saxulf was made bishop of Lichfield, ${ }^{2}$ and the same year Wulfhere died, and Æthelred succeeded to the crown. The Anglo-Saxon Chronicle names Cuthbald as Saxulf's successor in the abbacy, ${ }^{3}$ whether rightly or not admits of question. Certainly one Cuthbald governed the monastery at Oundle, when Wilfrid died there in $709,{ }^{4}$ and the connection of Oundle with Medeshamstede is rendered the more probable by the near neighbourhood of the two places, and by the fact that in later times we find Oundle dependent on Peterborough. Of the acts of Cuthbald we have no record ; of those of Ethelred and Saxulf during his supposed pontificate we have a good deal. It seems not improbable, considering the active part that Saxulf took in the management of the abbey, after he was made bishop, and even during the short period in which it was cut off from his ordinary jurisdiction by the episcopate of Cuthwin at Leicester, that he may have retained the abbacy in his own hands, as Wilfrid tried to do at Hexham and Ripon, Aldhelm at Malmesbury, and S. Ecgwin at Evesham. Very possibly the name of Cuthbald is a hap-hazard introduction into the list, founded on Bede's mention of him.

${ }^{1}$ For example, Fiscerton (temp. R. Edw. Conf. C.D. 808). Ketering ( $\mathrm{T}$. Eadwi, C.D. 443).

Bredun, Hrepingas, Cedenac (temp. Ethelredi Merc.).

Peykirk: temp. Edmund Atheling (C.D. 726), \&c.

The grant is indeed so drawn up as to includeall benefactions real and supposed, vOL, XVIII. ever made or supposed (from misused charters) to have been made to Peterborough down to a late epoch.

2 Saxulf's foundation of Thorney, Ancarig, extremely dubious. H. Candidus, p. 6, \&c.

3 Chr. S. 657 .

4 Bede, V. 19. 
In the first place we have a charter, ${ }^{1}$ the genuineness of which I see no reason to doubt, although Kemble has not printed it in the Codex Diplomaticus, being stated in the form of record, not of a direct donation. In this (Monasticon I. 345) Athelred, the glorious King of Mercia, on the occasion of a visit to Medeshamstede, gave to the brethren he found there thirty manentes at Leugtricdun, and confirmed the gift by placing on the Gospels'Book a sod taken from the place. The act was witnessed by Bishop Saxulf; Berhthun and Wecca, monks ; Osthrytha, the queen ; Herefrith and Eadferth, ealdormen. This is from the MS. LX. Soc. Ant. From the same source we have the following curious account of the affiliation of a monastery at Bredun. ${ }^{2}$ Friduric, the ealdorman, was the most religious of all the princes of Athelred. The name is strange to us, save from this place; but one Friodored was an ealdorman of Mercia in 704, and is, probably, the person meant. ${ }^{3}$ He was a man full of the missionary spirit, and, desiring to spread the knowledge of the faith and the gifts of the sacraments, founded a church at Bredon, for which he desired the monks of Medeshamstede to find an abbot. They appointed Hedda, who was, however, directed to consider himself still a monk of Medeshamstede. He did his work so well that Friduric afterwards gave him, in addition to Bredon, twenty-six manentes in Hrepinges, and, riches increasing, enabled him to buy of King Fithelred fifteen manentes at Cedenanác, for a variety of presents to the value of 500 shillings; they are thus enumerated: the furniture of twelve beds, pillows of feathers adorned with embroidery, linen sheets and British coverlets, a man-servant and maid, a golden fibula with four golden bosses (massiuncula) of fine work, and two horses, with two "cannis," whatever they were. The bargain was ratified at Tonitun, ${ }^{4}$ in the king's chamber, by joining of hands, and by placing a sod from Cedenanác on the Gospels' Book, in the presence of Bishop Saxulf.

The question naturally arises, What Bredon is this? The best known place of the name is Breodun, or Briudun, in

1 MS. Soc. Ant. LX. f. 36 . Mon. Ang. I. 345 .

2 MS. Soc. Ant. LX., f. 39 b., 40 . This document will be found appended to this memoir.

${ }^{3}$ Friodored, Kemble, C.D. Ch. 52 .
Ao. 704.-Frithurie, ibid, ch. 99 and 98 , Ao. 749. His relics are at Bredon Hugh Cand. p. 3.

4 Possibly Tomitun, the capital of the Tonseti, or Homtun, i. e., Northampton. 
the Hwiccas, from which Archbishop Tatwin came, ${ }^{1}$ and which was subsequently absorbed into the cathedral monastery of Worcester ; but this seems too remote to be a colony from Medeshamstede,-nor is our Bredon, so far as I am aware, ever spelled Breodun or Briudun. Tanner supposes it to be Bradden, in Northamptonshire, and Kemble, in his Index, favours the guess. I am inclined rather to Bredon, in Leicestershire, by the occurrence of Hrepinges as a neighbouring estate, probably in the Hundred of Repington. Cedenanác may be found possibly in Charnwood Forest; certainly it cannot be Cadney, in Lincolnshire, as supposed by the translators of the Chronicle.

I may mention, apropos of Bredon, that there are two charters-or, rather, two forms of the same charter,-executed by Berhtulf, King of Mercia, in 848, granting certain immunities to the House and to Eanmund the Abbot. ${ }^{2}$ One of these, the spurious form, occurs in the Worcester Chartularies, the authentic one in the Peterborough Chartulary ; the same question arises about both. The probability is that it properly belongs to the Worcestershire Bredon, and fell into the hands of the Peterborough collectors at the restoration, the spurious charter being fabricated to supply its place. But I cannot speak with any confidence on the question.

The Peterborough chroniclers, feeling; perhaps, the weakness of the fabrication of Vitalian's privilege, attempted their highest flight in forgery in the pretended bull of Pope Agatho. ${ }^{3}$ This exists in two forms : a mild abstract in the Chronicle, a lengthy Latin effusion in the Chartularies. By it the Abbot of Medeshamstede is constituted legate of Rome all over England, the monastery is exempted from all taxes, it is made as a place of pilgrimage equal in pardons, \&c., to Rome herself. On the reception of it the king is represented as ordering it to be read at the synod of Heathfield, and taking the opportunity to confirm the grants of Wulfhere. It is a most shameless forgery.

I have said that it is doubtful whether Cuthbald was the successor of Saxulf; if he was, he probably was identical with Wilfrid's friend. No more is known of him. His

1 Tatwin was a Gyrvian name.

2 Kemble, C.D. 248 and 261.
3 Kemble, C.D. 990 . Mon. Angl. I. 378. Chron. S. 675. 
successor is stated to have been Egbald. He is involved in thicker darkness than Cuthbald, for his name only occurs in a grant by Ceadwala, confirmed by the kings of Kent, and by Athelred and Saxulf, of land at Hogh, in Heburheage in Kent, made to Abbot Egbald, and confirmed at Medeshamstede.' This grant (which contains an anachronism sufficient to invalidate it, were it not that it has certainly suffered in transcription, and is not now in its original form, viz., making Saxulf, who died in 691, contemporary with Wihtred, who began to reign in 694) is of course no proof that either Egbald or Hogh ever belonged to Medeshamstede.

Saxulf died in 691 or 692 , in possession of both the sees, Lichfield and Leicester ; ${ }^{2}$ at Lichfield he was succeeded by Hedda, probably the same as the Abbot of Bredon; at Leicester by S. Wilfred, the exiled Bishop of Northumbria, who found a wise friend and supporter in Athelred. He was not without other friends in Mercia : S. Etheldreda had been his favourite pupil ; Beorhtwald, the son of Wulfhere, had been his benefactor in the utmost need. ${ }^{4}$ The few years he spent at Leicester were probably the most quiet of his life. To this period we may safely ascribe the foundation of the monastery at Oundle, where he died. He was restored to his beloved Hexham in 705, after several years' litigation, and Medeshamstede, with the rest of the diocese of Leicester, was restored to Lichfield until 737.

From this point the fasti of Medeshamstede are blank for many years. The Chartulary tries to fill up the space with a privilege of Pope Constantine granted to two monasteries dedicated to S. Peter, at Bermondsey and Woking in Surrey, under the government of an Abbot Hedda. ${ }^{5}$ Hugo Candidus was acquainted with this document, as with the whole contents of this part of the Chartulary, ${ }^{6}$ and tries to account for the connexion by supposing that cells, or affiliated abbeys to Medeshamstede, had been founded at Thorney, Bricklesworth, Bermondsey, Woking, and Hreping, as well as at Bredon. Later antiquaries have endeavoured to identify Bermondsey with Wermington, and Woking with Wicken $;^{7}$ but the privilege of Constantine places both in Wessex ; of their identity

1 Kemble, C.D. 40. MS. Soc. Ant. LX. f. 31. Mon. Angl. I. 384. Chron. Sax. 686.

${ }^{2}$ Eddius, Vita Wilfridi, p. 75.

3 Bede, IV. 19.
4 Edd. p. 71.

5 MS. Soc. Ant. LX. fo. 50, b. Printed at the close of this memoir.

6 Hugh C. p. 9.

7 Mon. Angl. I. 315. 
there is no doubt. This document, whether genuine or not, is very curious; and I am not inclined to doubt its authenticity, as we have so few monuments of the same age to compare it with, ${ }^{1}$ and it is impossible to guess what could be the object of such a forgery. No monastery is from other sources known to have existed at Bermondsey before the conquest, and the existence of one at Woking is only proved by another document in the same collection. ${ }^{2}$

The privilege is to the following effect. Constantine, after saluting Abbat Hedda, and stating the duty of encouraging the persevering profession of monachism by immunities, grants to these two houses exemption from episcopal jurisdiction in temporals. They are to elect their own clergy and their own abbots, who are to be ordained and blessed by the bishop of the diocese, after careful examination; he is, also, to have a right of examining into moral abuses, but the administration of the property of the monasteries is to be managed without any interference from any one. In a word, the bishop is to have the right of inquiring into matters canonical, the abbot is not to be interfered with in the management of the property. It is difficult to see how this and the companion charter ever got to Medeshamstede. Perhaps the common dedication to S. Peter was the link of connexion; possibly Bermondsey was a colony of Medeshamstede; possibly the ocourrence of the name of Hedda, so prominent in all these documents, may have caused it to be brought to Medeshamstede, when the name of S. Peter at Bermondsey was forgotten, and the burgh of S. Peter was residuary legatee to all the effects of defunct houses of that dedication. The other grant I refer to is printed by Kemble, C.D. 168; it is a grant of immunity by Offa to Pusa, abbot of Woking; its date is between 786 and 796 . It contains no reference to Medeshamstede. It is, therefore, a mere invention of the chroniclers to make Pusa the fourth abbot here ; we shall see that at this time the seat was otherwise filled.

Bothwin appears to have been abbot from 758 to 789 . $\mathrm{He}$ is not mentioned by any of the local historians, but his

I Cf. Bulls of Constantine to Evesham, Wilkins, Conc. I. 74, and Mon. Angl. II. 14. Spelman I. 212.
${ }^{2}$ Mon. Angl. I. 380. Kemble, C.D. 168.

${ }^{3}$ Chron. S. 777. H. Candidus, p. 13. 
character and place are clearly marked by a charter in the Textus Roffensis-Kemble, C.D. 113. In it Offa confirms a grant made to Eardulf, Bishop of Rochester, in the monastery of Medyshaemstede, under the presidency of Abbot Bothwin; Bothwin himself subscribes as witness to this and very many charters of Offa. We lose sight of him at the synod of Cealchythe, in 789. He was a correspondent of Lullus, Archbishop of Mentz, and wrote the 82nd Epistle among those of Boniface. ${ }^{3}$ He must not, I think, be confounded with Bothwin, Abbot of Ripon, who died in $786 ;^{2}$ for although it is possible that there was a close connexion between the two abbeys of S. Peter, it is hardly likely that they were under the same abbot. Mabillon does indeed make Cuthbald Abbot of Ripon, but wrongly, ${ }^{3}$ for Tatberht succeeded Wilfred there. ${ }^{4}$ The only fact that seems to favour the notion is that Hugo Candidus, in his list of relics, enumerates among those of Peterborough the remains of Wilfrid, Botwin, Sigfrid, and Tadberht, all abbots of Ripon.

If Botwin died or resigned in the synod of Cealchythe in 789 , his successor was immediately appointed. This was Beonna, who signs Mercian charters down to 805 . One act of his abbacy survives. He granted to Cuthbert, the ealdorman, ten manentes at Swineshead for 1000 shillings and one night's feorm fultum every year for two generations. ${ }^{5}$ This is between 789 and 796 .

In 803 Abbot Beonna attended the great council of Clofesho, with the other abbots of the diocese, under Werenberht, Bishop of Leicester. ${ }^{6}$ He signs the act passed against secular interference with monasteries, second among the abbots of Werenberht. Soon after this his name disappears from the charters, nor do we find a successor for some years. Possibly this Beonna is the same who was made Bishop of Hereford in 823, and died in 830. The relics of Abbot Beonna, according to Hugo Candidus, lie at Bredon. ${ }^{7}$

Abbot Ceolred is also an historical person; he executed a

1 Epp. Bonif. Ed, Serar, p. 116.

2 Chron. S. 785.

3 Mabillon, Acta SS. Bened. III. p. 687.

4 H. Cand. p. 36. Mon, Angl. II. 131.
5 Chron. S. 777. MS. Soc. Ant. LX. fo. 36 . Kemble, C.D. 165 .

6 Kemble, C.D. 1024.

7 H. Cand. p. 39. 
grant of land at Sempingham in 852 to Wulfred. ${ }^{1}$ This is extant in Anglo-Saxon, and is signed by Ceolred abbud, Aldberht præpositus (or prior), Alcheard, Eanred, Wilheard, Cenferth, Cyneweald, Eadwald, priests ; Humberht and Ecgberht, deacons ; and two others, who may have been simple monks.

The last name on our list is that of Abbot Hedda. We must not suppose that, because he is mentioned by Ingulf, he is necessarily a myth ; we may conclude from the mention of him in the Chronicle at 963 , that he was, traditionally, the last Abbot of Medeshamstede. In his name is drawn up the relation of the founding of the abbey to which I have referred; and he hid in the walls the title-deeds of $\mathrm{Me}$ deshamstede, which were said to be discovered in 963 , but many of which were fabricated after the restoration.

I have reviewed most of these supposed recovered deeds ; some of them, as the Swineshead and Sempingham charters, are real Medeshamstede relics; others, like the Woking and Bredon charters, are genuine documents, but with only a conjectural connexion with this house, and may have been picked up by some ignorant or designing collector anxious for the glory of Peterborough.

I do not wish, however, to make any sweeping assertion about these last; we know that the title to an estate of bócland was sometimes conveyed by the transfer of the deeds (libri, or libelli) without a formal record of the transfer. Bermondsey and Woking may, at some unknown point of time, have belonged to Medeshamstede, but there is no evidence about it; and a mere presumption on such grounds, such as that of making Pusa Abbot of Medeshamstede, is quite inadmissible.

Before we go on to the destruction of the Fen monasteries by the Danes, I will say a few words on the fasti of Croyland.

Guthlac, an Iceling, of the royal house of Mercia, retired to the marshes of Croyland about 700, and lived there as a hermit until 716. ${ }^{2}$ He had been a pupil of Abbess Elfthrytha, at Repandune, and was a friend of Ethelbald, King of

1 Chron. S. 852. Kemble, C.D. 267.

2 Vita S. Guthlac, Mab. Acta SS. Ord. Bened. III., and MS. Cotton. Nero E. 5, which does not contain the final paragraph on the foundation of Croyland Abbey. 
Mercia, when in exile. $\mathrm{He}$ was ordained by Hedda of Lichfield, between 705 and 716, in which year he died. His sister, Pega, lived at Peykirk. Ecgburga, an abbess, daughter of Aldwulf, of East Anglia, sent him his coffin. So much we know from his biographer Felix. From Ordericus we know that Ethelbald gratefully founded an abbey on the site of Guthlac's hermitage, and made Kenulf, a monk of Evesham, the first abbot. ${ }^{1}$ To him, according to the pseudo-Ingulf, an abbot named Patrick succeeded. ${ }^{2}$ Singularly enough, there is a document extant in which an Abbot Patrick occurs : it is printed in Wilkins' Concilia $;^{3}$ it is a letter from Pope Paul to Egberht, Archbishop of York, remonstrating with him for having taken away three monasteries, Donamuth, ${ }^{4}$ Coxwold, and Stanengrave, from Abbot Forthred, and giving them to his brother, Patrick Moll. Forthred was a Mercian abbot, and a friend of Alcuin ; $;$ he signs the acts of Clofesho next after Beonna: possibly Croyland may have been his abbey, and Patrick (if, indeed, the name is not merely the Latin for ealdorman) may have been an interloper. Of Siward, his successor, and Theodore, the last abbot, we know nothing, except from Ingulf. The names may be traditional - they look like fabrications. The whole history is, in fact, so much adulterated ${ }^{6}$ that, if it were not for the direct testimony of Ordericus and W. Malmesbury, we should doubt the existence of an abbey at Croyland altogether. Alfrida, the betrothed of Ethelberht and daughter of Offa, found a hermitage there, and so, according to Malmesbury, did S. Neot.

In 870 the Danes, under Ingwar and Hubba, devastated East Anglia and Mercia; then fell Ely, Medeshamstede, and Croyland. I should gladly believe the interesting account given in Ingulf to be more than a romance ; the fact, however, that no mention is made of the circumstances so

1 Orderic. Vit. IV. 17.

2 In the MS. Vesp. B. XI, which contains the lives of the Abbots of Croy. land down to 1427 , there is no name between Kenulf and Thurkytel, no destruction by the Danes, and no chancellorship.

3 Wilk. Conc. I. 144.

4 Donamuth: . Sim. Dun: H. Hunt. and Chr. S. at 724, where Donemuth is said to be a mistake for Thone muth-
Weremouth. This record shows that there was a house of this name.

5 Alcuin. Ep. 160. Ed. Froben.

6 Cf. Croulan, founded by S. David. Gir. Cambr. Ang. S. II. 632.

7 According to Ingulf, the desolation of the monasteries was completed by Beorred, king of Mercia, who confiscated all the monastic lands in his dominions belonging to Medeshamstede, Peykirk, Croyland, and Bardney. 
detailed, either by Orderic or Malmesbury, or by the industrious later compilers, is, in my opinion, fatal. Malmesbury even goes so far as to say that, by the intercession of $\mathbf{S}$. Guthlac and S. Neot, Croyland had never suffered grief or loss.

The companion houses lay desolate, according to the historians, for 100 years, at the termination of which time Croyland was restored by Thurkytel. This man, whom Ingulf has exalted into a saint and statesman of the first rank, is known only to historical students as a turbulent priest, a kinsman of the Archbishop Oskytel, of York, and of the Danish royal family of East Anglia (for it is obvious that his connexion with the house of Cerdic is a fable). At one time he was Abbot of Bedford, then turned out of Bedford, and buying a canonry at S. Paul's. In another chronicle he appears as Abbot of Ramsey, but this is possibly a mistake for Croyland, of which he was undoubtedly proprietor and benefactor.

Perhaps owing to his example S. Ethelwold restored Ely, Thorney, and Medeshamstede, and Archbishop Oswald founded Ramsey.

I have now brought the subject and period I have undertaken to a close. The details are meagre-very little, I fear, in exchange for the abundant information which we are forced to decline from the pseudo-Ingulf and his copyist ; but much more satisfactory, as I believe every step to be carefully tested, and nothing admitted that is not witnessed to by most probable evidence. If we have built up but little, we may console ourselves with having cleared the ground of much very bad building material.

\section{Extracts from the Black Book of Peterborodgh.}

THE following documents are taken from the Register in the Library of the Society of Antiquaries of London (MSS. No. 60), entitled-" Iste Liber vocatur Niger Liber, Anglice, the Blak Bowke." It is the more ancient of two Peterborough Registers presented to the Society by the Earl of Exeter in 1778, and of which full Indexes have been published in the new edition of Dugdale's Monasticon, vol. i. pp. 372-375. It has appeared desirable to print the documents here given, to which reference has been made in the foregoing Memoir, being the only portions of the contents of the older part of the Black Book which have not already been printed, either in the Monasticon, in Kemble's Codex Diplomaticus, or in the Appendix to the Chronicon Petroburgense, edited by the late Mr.

VOL. XVIII. a $a$ 